\title{
Anti-OX40 Monoclonal Antibody GSK3174998
}

National Cancer Institute

\section{Source}

National Cancer Institute. Anti-OX40 Monoclonal Antibody GSK3174998. NCI Thesaurus.

Code $C 124783$

An agonistic humanized immunog lobulin G1 (IgG1) monoclonal antibody against the cell surface receptor OX40 (CD134; T NFRSF4), with potential immune checkpoint inhibitory and antineoplastic activities. Upon administration, anti-OX40 monoclonal antibody GSK3174998 selectively binds to and activates OX40. Receptor activation induces proliferation of memory and effector T-lymphocytes and results in a T-cell-mediated immune response against tumor cells, which leads to tumor cell lysis. OX40, a cell surface glycoprotein and member of the tumor necrosis factor receptor superfamily (TNFRSF), is expressed on T-lymphocytes and provides a co-stimulatory signal that promotes both the proliferation and survival of activated T-cells. 